\title{
Microbiological and genetical identification of some vermicompost beneficial associated bacteria
}

\author{
Soltan, H.A.H. ${ }^{1 *}$, O.F. Dakhly ${ }^{2}$, M.A. Mahmoud ${ }^{2}$ and Yasmen F.M. Fikry ${ }^{2}$ \\ ${ }^{1}$ Central Laboratory of Organic Agriculture, Agriculture Research Center, 12619, Giza, Egypt. \\ ${ }^{2}$ Genetics Department, Faculty of Agriculture, Minia University, 61519, Minia, Egypt.
}

\begin{abstract}
In the present work, isolation and identification of some plant beneficial bacteria of vermicompost were conducted. A total of ten bacterial isolates were selected and characterized morphologically and biochemically. Molecular characterization of the bacterial isolates using 16S rRNA gene sequence analysis and phylogenic tree were conducted. According to the percentages of homology of $16 \mathrm{~S}$ rRNA sequence with the closest NCBI strain, all of the ten bacterial isolates were belonged to six species (B. subtilis, B. atrophaeus, B. hemicentroti, B. velezensis, B. nakamurai and B. amyloliquefaciens) of genus Bacillus. Except isolate YFV05 which showed only $99.77 \%$ of homology with Bacillus subtilis strain NRRL NRS-744, all of the other isolates showed 100\% homology to different strains of Bacillus spp. Generally, results revealed that all the ten bacterial isolates had different levels of in vitro antagonistic effect against four phytopathogenic fungi (Fusarium solani, Fusarium spp, Macrophomina phasolenia, and Rhizoctonia solani). In addition, treatment with YFV014, YFV05 and YFV012 isolates offered the highest values of vigor index (2166.0, 1775.0 and 1733.6), respectively. Finally, it could be concluded that plant beneficial bacteria might be isolate from vermicompost which in turn can be used to improve plant growth directly by production of plant growth-regulating hormones and enzymes and indirectly by controlling plant pathogens and other pests, thereby enhancing plant health and minimizing the yield loss of various crops.
\end{abstract}

Keywords: 16S rRNA; Bacillus spp; Gene sequencing; Vermicompost.

\section{Introduction}

Recently, under the modern agricultural systems, chemical fertilizers play an important role in crop production improvement. But the numerous and continuous application of chemical fertilizers had hazardous effect on environment and human health (Gupta et al., 2015; Hartman and Tringe, 2019). It causes highly decrease in beneficial microorganism which led to soil sterility and becomes unfit for agricultural process. Hence, increasing soil fertility by

\footnotetext{
*Corresponding author: Hassan A.H. Soltan, Email: soloo2525@gmail.com

Received: December 3, 2021; Accepted: December 29, 2021; Published online: January 2, 2022. (C) Published by South Valley University. This is an open access article licensed under cc)(이이
}

adding different sources of natural organic fertilizers such as, composts, vermicompost, farmyard manure and bio-fertilizers has been developed to maintain the sustained productivity of different crops (Bhawalkar, 2004). Vermicomposting is a non-thermophilic biological oxidation recycling process which converted the organic matter to vermicompost with a high porosity, aeration, drainage, water holding capacity and improves plant growth by increasing beneficial microbes due to the interactions between earthworms and their associated microorganisms (Hashimoto et al., 2021; Zhu et al., 2017; Pathma and Sakthive, 2012).

Earthworm enhance the activity and growth of certain microbial species, thereby it improves the physiochemical properties of the 
soil. The vermicompost microbes play an important role in improving crop production as well as conserving the stability of the soil structure. Various bacterial genera were found in vermicompost and this depends on the environmental condition and the raw materials which used in the vermicomposting process (Satpathy et al., 2020).

Earthworms absorb Plant Growth Promoting Rhizobacteria (PGPR) such as Bacillus, Pseudomonas, Rhizobium, Azosprillium, Azotobacter, etc. from rhizosphere, and they might get activated or increased due to the typical environment of the gut (Sinha et al., 2010). Vermicompost is an organic fertilizer, which is an eco-friendly organic material, containing essential elements derived from $95 \%$ of worm droppings and $5 \%$ of material resulting from the decomposition of microorganisms that is important for enhancing physio-chemical and biological properties of the soil (Aritonang and Sidauruk, 2020). Treatment of the soils with vermicompost can be improve plant growth, increase the beneficial rhizospheic microbes and minimize plant pathogens (Munoz-Ucros et al., 2020).

Nowadays, nucleic acid sequencing technologies and their applications have become widely used as a powerful tool for bacterial characterization and classification at species level. Using PCR technique and sequencing of $16 \mathrm{~S}$ rRNA gene is wildly used to identify and determine the genetic diversity of prokaryotes as well as the prediction of phylogenetic relationships (Pace, 1997) in various samples such as; compost (Denizci et al., 2010; Bandounas et al., 2011), anaerobic sludge (Riviere et al., 2009), dairy farms, natural environment (Mulder et al., 2005; Pandey et al., 2016), and in vermicompost (You et al., 2019; Cai et al., 2018).

Molecular and microbiological characterization of bacterial community of vermicompost showed that the most of genera were related to Firmicutes, Proteobacteria,
Actinobacteria, Planctomycetes and Bacteroidetes (Yasir et al., 2009a).

So, the aims of this study were to isolate and identify the vermicompost beneficial associated bacteria via microbiological and molecular techniques, as well as evaluating their potential role in plant growth promotion in addition to their in vitro antagonistic activity against some phytopathogenic fungi.

\section{Materials and methods}

The present experiments were carried out in Genetics Department Faculty of Agriculture, Minia University and Central Lab. of Organic Agriculture (CLOA), Agriculture Research Center (ARC), Giza, Egypt.

\subsection{Sample collection}

Vermicompost sample was obtained from the unit of vermicomposting at Central Laboratory of Organic Agriculture (CLOA), Agriculture Research Center (ARC), Giza, Egypt in a sterilized beaker.

\subsection{Isolation of vermicompost associated bacteria}

Potato Dextrose Agar (PDA) medium was used for vermicompost associated bacteria isolation. One gram was taken in a sterilized conical flask containing $100 \mathrm{ml}$ of sterile

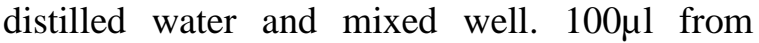
appropriate serial dilutions were spread plated on respective PDA medium then incubated at $37^{\circ} \mathrm{C}$ for 24 hours. Different single colonies were isolated and stored at $4^{\circ} \mathrm{C}$.

\subsection{Characterization of vermicompost associated bacteria}

The bacterial isolates were characterized owing to their morphological, microscopic and biochemical properties.

\subsection{Morphological tests}

Cell shape, gram reaction, and bacterial motility were studied to morphological characterization of the vermicompost associated 
bacteria. the cell morphological characteristics of the purified cultures, at log phase were microscopically observed according to Aneja (2006). Gram's staining was performed to determine stain ability (gram negative or gram positive) of the vermicompost bacterial isolates according to Hucker and Conn (1923). The ability of bacteria isolates to move by itself in semi-solid nutrient agar plates $(0.2 \%$ agar) were conducted according to Elbeltagy et al. (2000).

\subsection{Antibiotic resistance}

Antibiotic resistances test was performed on Nutrient Agar (NA) medium supplemented with one of these antibiotics ( $\mu \mathrm{g} / \mathrm{ml})$ : Colistinn CT (10); Streptomycin S (10); Clindamycin DA (2); Penicillin P (10); Azithromycin AZM (15); Nitrofurantoin F (300); Ceftriaxone CRO (30) and Amikacin AK (30). The effects of antibiotic resistances were determined by measuring the zones around antibiotic discs to determine the resistances and sensitive of each antibiotic according to Clower and Hay (1968).

\subsection{Biochemical tests}

\subsubsection{Oxidase test}

The production of cytochrome c oxidase by bacterial isolates was tested as described by Cappuccino and Sherman (1996).

\subsubsection{Catalase activity}

was carried out as described by Aneja (2006).

\subsubsection{Indole production}

After $48 \mathrm{~h}$ of incubation into glucose tryptone broth, indole production was detected by reddening of the alcohol layer within few minutes after adding and mixing $0.3 \mathrm{ml}$ of Kovacs reagent (Seeley and Vandemark, 1981).

\subsubsection{Gelatin hydrolysis}

The activity of the gelatinase enzyme for hydrolyzing gelatin was verified by gelatin liquefaction as described by Aneja (2006).

\subsubsection{Starch hydrolysis}

The ability of bacterial isolates to hydrolyze starch by producing amylase enzyme was conducted according to Aneja (2006).

\subsection{Molecular identification of vermicompost associated bacterial isolates}

\subsubsection{Genomic DNA isolation}

Total genomic DNA of ten bacterial isolates was extracted by Cornel extraction buffer $(500 \mathrm{mM} \mathrm{NaCl} ; 100 \mathrm{mM}$ Tris- $\mathrm{HCl}, \mathrm{PH}$ 8.0; $50 \mathrm{mM}$ EDTA and $0.84 \%$ SDS) according to (Kiruthika and Padmanabha, 2018). Additional requirements [freshly prepared Lysozyme buffer $(20 \mathrm{mg} / \mathrm{ml})$, phenol: chloroform: isoamyl alcohol (25: 24: 1), 96\% 100\% Ethanol, RNase $(50 \mathrm{mg} / \mathrm{ml})]$ were used. The extracted DNA was dissolved in 100 $\mu \mathrm{l}$ TE buffer and used as the template for the PCR reactions.

\subsubsection{Amplification and analysis of $16 S$ rRNA gene}

The 16S-rRNA gene fragment was amplified using universal bacterial Forward (5'AGAGTTTGATCCTGGCTCAG-3') and Reverse (5'-ACGGCTACCTTGTTACGACTT3') primers (Patel et al., 2012). PCR amplifications were performed in a total volume of $50 \mu \mathrm{l}$ by mixing $4 \mu \mathrm{l}$ of the template DNA with $2 \mu \mathrm{l}$ from each primer and $17 \mu \mathrm{l}$ of sterilized double distilled water then complete final volume by adding $25 \mu \mathrm{l}$ with $10 \mathrm{X}$ Dream TaqTM Green Buffer. PCR amplification was carried out with the following optimized conditions: Initial denaturation at $94^{\circ} \mathrm{C}$ for 3 minutes, denaturation at $94^{\circ} \mathrm{C}$ for 30 seconds, primer annealing at $57^{\circ} \mathrm{C}$ for 30 seconds, chain extension at $72^{\circ} \mathrm{C}$ for 2 minutes and a final extension at $72^{\circ} \mathrm{C}$ for 10 minutes. Denaturation, annealing and extension cycles were repeated for 30 cycles. Sequencing of the purified DNA samples was performed at GATC Company (GATC Biotech Ltd. - The London BioScience Innovation Centre - London, United Kingdom) 
by using $\mathrm{ABI}$ 3730xl DNA sequencer. The obtained sequences were compared to sequences in the public database using Basic Local Alignment Search Tool (BLASTn) on the website (http://www.ncbi.nih.gov) in order to determine similarity to sequences in the GenBank database (Shayne et al., 2003). All $16 \mathrm{~S}$ rRNA gene sequences determined in this study have been deposited at National Center for biotechnology Information (NCBI) database and can be found under the accession numbers OK444809 to OK444818. The phylogenetic tree was constructed using the unweighted pair group method with neighbor-joining (NJ) method in MEGA X software package (Kumar et al., 2018).

\subsection{In vitro antagonistic activity against phytopathogenic fungi}

Four phytopathogens fungi e.g., Fusarium solani, Fusarium spp, Macrophomina phasolenia, Rhizoctonia solani were kindly obtained from the Central Laboratory of Organic Agriculture (CLOA), Agriculture Research Center (ARC), Giza, Egypt. The antifungal activities of the bacterial isolates against tested phytopathogens were performed by Dual culture assay (Wang et al., (2009). The inhibition of fungal growth was evaluated by the reduction percentage of mycelium expansion compared to control plates without bacteria following the formula of Whipps (1987) (R1-R2)/R1×100. All in vitro antagonism assays were made in triplicate. The percentages of growth inhibition were categorized on a growth inhibition category (GIC) scale from 0.0 to 4 , where $0.0=$ no growth inhibition; $1=1-25 \%$ growth inhibition; $2=26-50 \%$ growth inhibition; $3=$ $51-75 \%$ growth inhibition; $4=76-100 \%$ growth inhibition (Korsten and Jager, 1995).

\subsection{Evaluation of Plant Growth Promoting Activity}

To determine the efficiency of the vermicompost associated bacterial isolates on vegetative growth parameter of cowpea plants, plastic pots $(12 \mathrm{~cm}$ width) under greenhouse conditions were filled with $3 \mathrm{~kg}$ of sterilized soil/sand in $1: 1$ ratio. $100 \mathrm{~g}$ of sterilized vermiculite and $4 \mathrm{~g}$ of rock phosphate were added to sterilized mixture of soil. Three replicate pots were specified for each treatment in completely randomized experimental design. Five seeds of cowpea (Creeam 7) were coated with the tested isolates and planted in each pot and irrigated weakly. After 30 days of planting, cowpea seedlings were collected and the percentage of seed germination was calculated. Different growth parameters included shoot and root length, fresh and dry weight of shoot and root were measured. The vigor index (mean root length + mean shoot length $\times \%$ germination) was determined as described by Abdul Baki and Anderson (1973).

\subsection{Statistical analysis}

Statistical analysis was done using software MSTAT program (Version 4). The data were analysed using analysis of variance (ANOVA) and followed by least significance difference (LSD) at 5\% level (Gomez and Gomez, 1984).

\section{Results and discussion}

\subsection{Isolation of vermicompost associated bacteria}

Vermicompost associated bacteria were isolated from vermicompost sample cultured on PDA medium. A large number of colonies, differing in shape and nature of growth were observed (Figure 1). A total of ten single colonies showing different morphological appearances were selected for further characterization. These bacterial colonies were symbolized as YFV03, YFV04, YFV05, YFV06, YFV09, YFV011, YFV012, YFV013, YFV014 and YFV015. The huge number and 
variability of bacterial strains associated with vermicompost are in agreement with the results of Chaoui et al. (2003) who stated the high

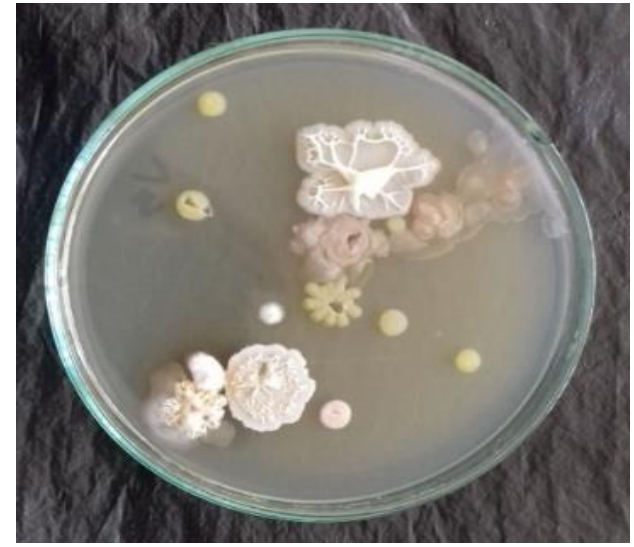

Figure 1. Variability in shape and nature of the vermicompost associated bacteria on PDA medium.

\subsection{Microbiological characterization of vermicompost associated bacterial isolates}

After colonies purification, some physiological and biochemical tests were conducted for characterizing the ten selected bacterial isolates as shown in Table (1). All cells of the pure bacterial isolates were rod-shaped, motile and gram positive. These results were in accordance with those of Begum et al. (2018) who reported that the vermicompost bacterial strains were positive to gram reaction with a rod shape. As shown in Table (1) all of the tested isolates gave positive results for catalase and oxidase activities that are responsible for protecting bacterial cells against different types of plant reactive oxygen (Fouts et al., 2008) and considered as an important aspect required by the bacteria to avoid cellular toxicity (Mbai et al., 2013). The obtained results showed that all bacterial isolates were positive for indole formation. Indole controls different shapes of bacterial physiology, such as formation of spore, stability of plasmid, drug resistance, biofilm formation, and virulence in bacteria (Lee and Lee, 2010). Moreover, IAA (natural plant growth regulator) production in the presence of tryptophan by all isolates reveals their

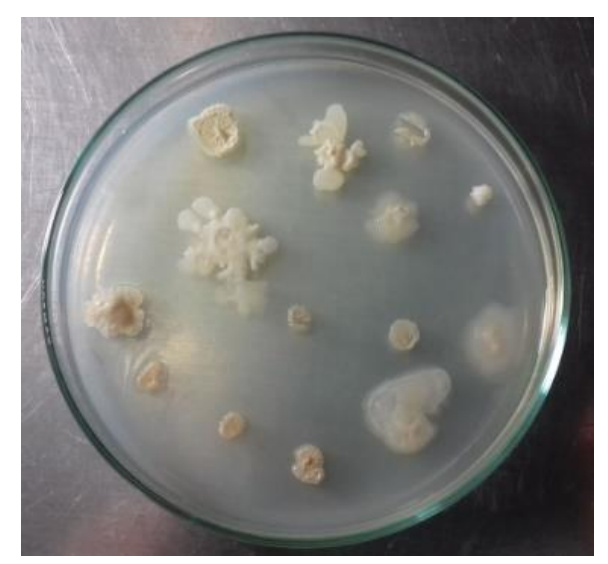

microbial diversity, particularly bacteria, fungi and actinomycetes in vermicompost.

capabilities for tryptophan utilization as a base for growth and production of IAA. Our results were in agree with that of (Sivasankari and Anandharaj, 2014) who found that all vermicompost bacterial isolates produced a considerable amount of IAA in medium, particularly Bacillus spp. isolates which showed higher IAA production than all other bacterial isolates.

The degradation of gelatin and starch is a vital process in terms of energy storage. The enzymatic activity of vermicompost associated bacterial isolates was studied in relation to gelatinase and amylase as shown in Table 1. All of bacterial isolates were able to produce gelatinase into nutrient gelatin deep tubes except of YFV06, YFV09 and YFV013. Gelatinase enzymes are produced by microorganism which had the ability to hydrolyze the gelatin into its sub-compounds (polypeptides, peptides and amino acids) that can cross the cell membrane and be used by the organism. Various types of gelatinase enzymes are found in several bacteria including Bacillus spp. (Balan et al., 2012). On the other hand, all bacterial isolates were able to display amylase activity which was indicated by the clear zones formation in starch agar media (Figure 2). 
Table 1. Microbiological and physiological profiles of the ten vermicompost associated bacterial isolates.

\begin{tabular}{lcccccccc}
\hline Isolates & $\begin{array}{c}\text { Cell } \\
\text { shape }\end{array}$ & Motility & $\begin{array}{c}\text { Gram } \\
\text { reaction }\end{array}$ & Catalase & Oxidase & $\begin{array}{c}\text { Indole } \\
\text { formation }\end{array}$ & $\begin{array}{c}\text { Gelatin } \\
\text { hydrolysis }\end{array}$ & $\begin{array}{c}\text { Starch } \\
\text { hydrolysis }\end{array}$ \\
\hline YFV03 & Rod & + & + & + & + & + & + & + \\
YFV04 & $"$ & + & + & + & + & + & + & + \\
YFV05 & $"$ & + & + & + & + & + & + & + \\
YFV06 & $"$ & + & + & + & + & + & + & + \\
YFV09 & $"$ & + & + & + & + & + & + & + \\
YFV011 & $"$ & + & + & + & + & + & + & + \\
YFV012 & $"$ & + & + & + & + & + & + & + \\
YFV013 & $"$ & + & + & + & + & + & + & + \\
YFV014 & $"$ & + & + & + & + & + & + & + \\
YFV015 & $"$ & + & + & + & + & + & + & + \\
\hline
\end{tabular}

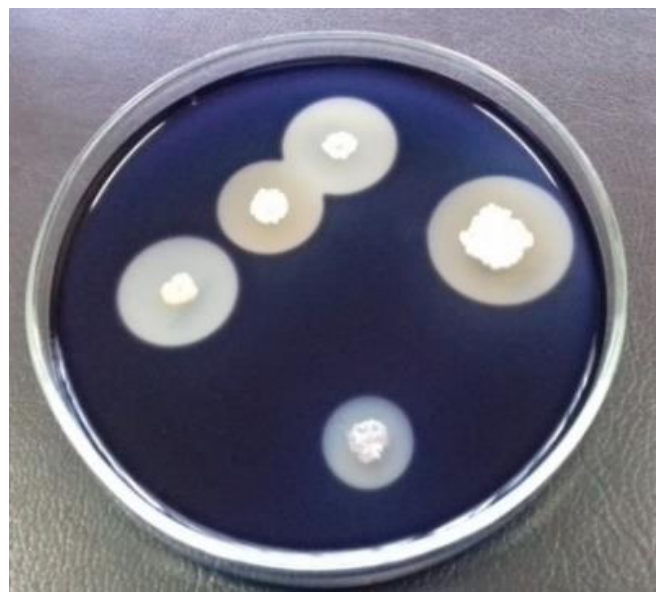

Figure 2. Amylase activity of vermicompost associated bacteria on starch agar medium.

\subsection{Antibiotic resistance test}

The actual antibiotic resistance of the ten bacterial isolates was verified on NA media supplemented with one of eight antibiotics Figure (3) and Table (2). The results indicated that all isolates had different levels of sensitivity to Streptomycin (10), Nitrofurantoin (300), Ceftriaxone (30) and Amikacin (30). On contrast, all isolates were resistance to Colistin (10) except isolate YFV015 which exhibited weakly sensitive to this antibiotic. The two isolates (YFV03, and YVF013) were resistance to Clindamycin (2), while the other isolates showed sensitivity to the same antibiotic. All isolates were resistant to Penicillin (10) except the two isolates YFV09 and YFV015 which showed weak and high sensitivity to this antibiotic, respectively. Concerning the Azithromycin (15), five isolates (YFV04, YFV04, YFV05, YFV011 and YFV014) were sensitive in NA medium, while the other isolates were resistant to the same antibiotic. Antibiotic resistance trait is a mechanism which microbes protect itself from unfavorable conditions. The variation in antibiotic resistance traits of microbes reflect the presence of various genes which are responsible for producing certain enzymes that able to detoxify the antibiotic and proteins that suppress the cellular transfer of the antibiotic (Hayes and Wolf, 1990). 
A

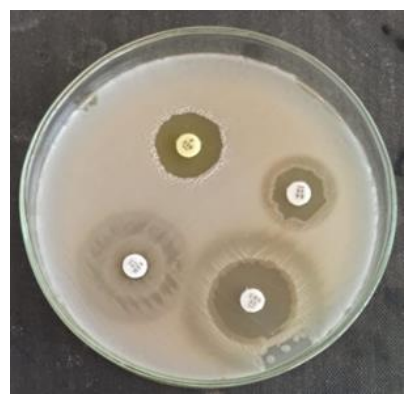

B

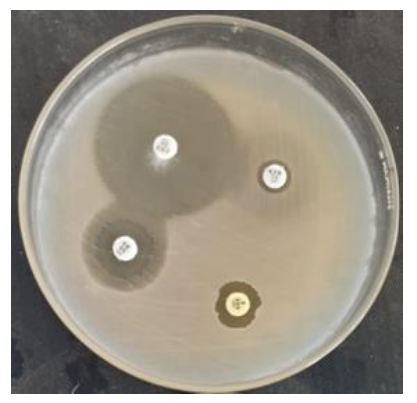

$\mathrm{C}$

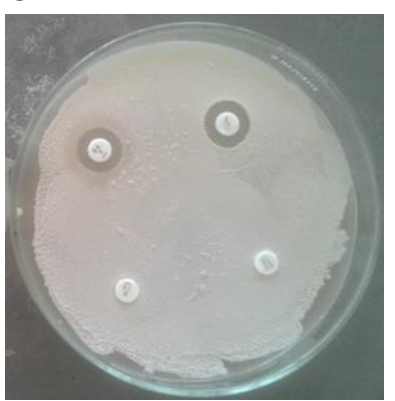

Figure 3. Effect of antibiotics on growth of vermicompost bacterial isolates. (A) Nitrofurantoin (300), Streptomycin (10), Colistin (10) and Clindamycin (2) on YFV015, (B) Amikacin (30), Ceftriaxone (30), Nitrofurantoin (300) and Azithromycin (15) on YFV05, (C) Colistin (10), Penicillin (10), Nitrofurantoin (300) and Amikacin (30) on YFV012

Table 2. Growth of vermicompost bacterial isolates on the presence of different antibiotics.

\begin{tabular}{|c|c|c|c|c|c|c|c|c|c|c|c|c|c|c|c|c|}
\hline \multirow[t]{2}{*}{$\begin{array}{l}\frac{\mathscr{0}}{0} \\
\frac{\pi}{0} \\
0\end{array}$} & \multicolumn{2}{|c|}{ 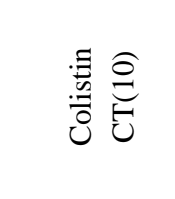 } & \multicolumn{2}{|c|}{ 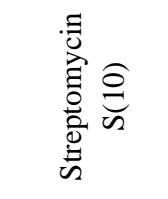 } & \multicolumn{2}{|c|}{ 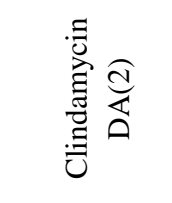 } & \multicolumn{2}{|c|}{ 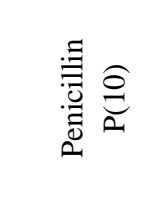 } & \multicolumn{2}{|c|}{ 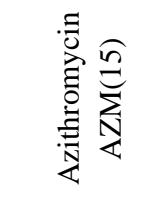 } & \multicolumn{2}{|c|}{ 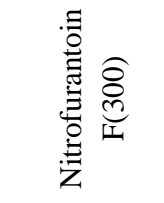 } & \multicolumn{2}{|c|}{ 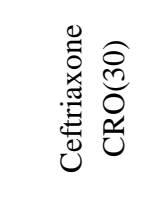 } & \multicolumn{2}{|c|}{ 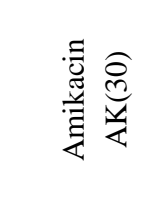 } \\
\hline & $\mathrm{D} / \mathrm{Z}$ & $\mathrm{R} / \mathrm{S}$ & $\mathrm{D} / \mathrm{Z}$ & $\mathrm{R} / \mathrm{S}$ & $\mathrm{D} / \mathrm{Z}$ & $\mathrm{R} / \mathrm{S}$ & $\mathrm{D} / \mathrm{Z}$ & $\mathrm{R} / \mathrm{S}$ & $\mathrm{D} / \mathrm{Z}$ & $\mathrm{R} / \mathrm{S}$ & $\mathrm{D} / \mathrm{Z}$ & $\mathrm{R} / \mathrm{S}$ & $\mathrm{D} / \mathrm{Z}$ & $\mathrm{R} / \mathrm{S}$ & $\mathrm{D} / \mathrm{Z}$ & $\mathrm{R} / \mathrm{S}$ \\
\hline YFV03 & 0 & $\mathrm{R}$ & 19 & $\mathrm{~S}^{+}$ & 0 & $\mathrm{R}$ & 0 & $\mathrm{R}$ & 5 & $\mathrm{~S}$ & 5 & $\mathrm{~S}$ & 16 & $\mathrm{~S}^{+}$ & 10 & $\mathrm{~S}^{+}$ \\
\hline YFV04 & 0 & $\mathrm{R}$ & 19 & $\mathrm{~S}^{+}$ & 11 & $\mathrm{~S}^{+}$ & 0 & $\mathrm{R}$ & 6 & $\mathrm{~S}$ & 7 & $S$ & 15 & $\mathrm{~S}^{+}$ & 9 & $\mathrm{~S}$ \\
\hline YFV05 & 0 & $\mathrm{R}$ & 13 & $\mathrm{~S}^{+}$ & 12 & $\mathrm{~S}^{+}$ & 0 & $\mathrm{R}$ & 5 & $\mathrm{~S}$ & 7 & $\mathrm{~S}$ & 20 & $\mathrm{~S}^{++}$ & 10 & $\mathrm{~S}^{+}$ \\
\hline YFV06 & 0 & $\mathrm{R}$ & 15 & $\mathrm{~S}^{+}$ & 15 & $\mathrm{~S}^{+}$ & 0 & $\mathrm{R}$ & 0 & $\mathrm{R}$ & 6 & $\mathrm{~S}$ & 10 & $\mathrm{~S}^{+}$ & 10 & $\mathrm{~S}^{+}$ \\
\hline YFV09 & 0 & $\mathrm{R}$ & 12 & $\mathrm{~S}^{+}$ & 8 & $\mathrm{~S}$ & 9 & $S$ & 0 & $\mathrm{R}$ & 6 & $\mathrm{~S}$ & 18 & $\mathrm{~S}^{+}$ & 10 & $\mathrm{~S}^{+}$ \\
\hline YFV011 & 0 & $\mathrm{R}$ & 13 & $\mathrm{~S}^{+}$ & 13 & $\mathrm{~S}^{+}$ & 0 & $\mathrm{R}$ & 7 & $S$ & 6 & $S$ & 15 & $\mathrm{~S}^{+}$ & 9 & $\mathrm{~S}$ \\
\hline YFV012 & 0 & $\mathrm{R}$ & 20 & $\mathrm{~S}^{++}$ & 19 & $\mathrm{~S}^{+}$ & 0 & $\mathrm{R}$ & 0 & $\mathrm{R}$ & 8 & $S$ & 19 & $\mathrm{~S}^{+}$ & 9 & $\mathrm{~S}$ \\
\hline YFV013 & 0 & $\mathrm{R}$ & 10 & $\mathrm{~S}$ & 0 & $\mathrm{R}$ & 0 & $\mathrm{R}$ & 0 & $\mathrm{R}$ & 6 & $S$ & 17 & $\mathrm{~S}^{+}$ & 6 & $\mathrm{~S}$ \\
\hline YFV014 & 0 & $\mathrm{R}$ & 15 & $\mathrm{~S}^{+}$ & 11 & $\mathrm{~S}^{+}$ & 0 & $\mathrm{R}$ & 6 & $S$ & 6 & $S$ & 14 & $\mathrm{~S}^{+}$ & 9 & $S$ \\
\hline YFV015 & 9 & $\mathrm{~S}$ & 17 & $\mathrm{~S}^{+}$ & 15 & $\mathrm{~S}^{+}$ & 22 & $\mathrm{~S}^{++}$ & 0 & $\mathrm{R}$ & 7 & $\mathrm{~S}$ & 12 & $\mathrm{~S}^{+}$ & 5 & $\mathrm{~S}$ \\
\hline
\end{tabular}

Abbreviations: Resistant (R); Weakly Sensitive (S); Sensitive (S+); Highly Sensitive(S++); Diameter (mm) of Zone around Antibiotic (D/Z).

\subsection{Molecular identification of vermicompost associated bacteria isolates}

Recently, nucleic acid sequencing technology applications have become widely used as a powerful tool for identifying and classifying bacteria at species level. Analysis of the bacterial 16S rRNA gene sequence became a preferred genetic technique to identify undescribed, rarely isolated, or phenotypically abnormal bacterial strains (Clarridge, 2004). The amplification of the 16S rRNA gene of the ten vermicompost bacterial isolates exhibited a band of 1500 base pairs (bp) (Figure 4).

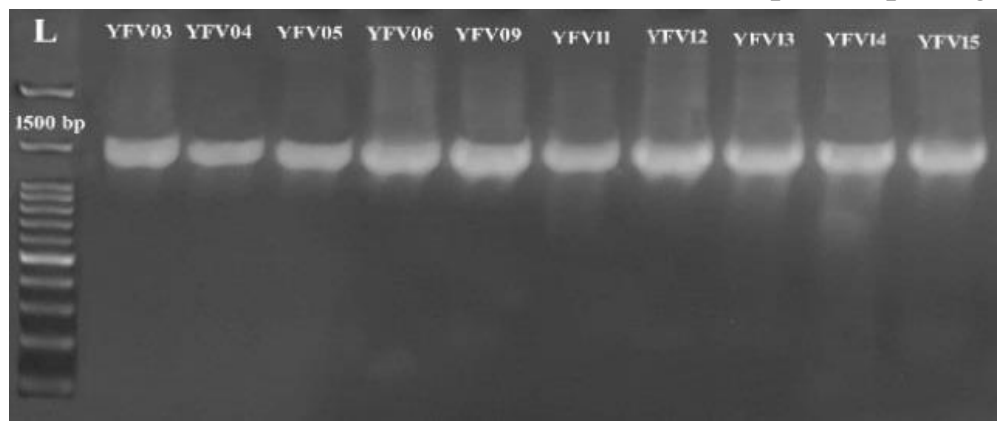

Figure 4. Electrophoretic patterns of 16S rRNA gene of the ten bacterial isolates. L: 100 bp ladder marker and lanes YFV03 through YFV015 refer to vermicompost bacterial isolates. 
The amplified fragments of the ten vermicompost bacterial isolates were subjected to nucleotide sequencing using the same primers. The nucleotide sequence data have been deposited in the NCBI GenBank under the accession numbers shown in Table (3). According to the percentages of homology of $16 \mathrm{~S}$ rDNA sequence analysis with the Closest NCBI strain(s) stored in Genbank database, the ten bacterial isolates in the present work were related to the same genus (Table 3). Except isolate YFV05 which showed only $99.77 \%$ of homology with Bacillus subtilis strain NRRL NRS-744, all of the other isolates showed 100\% homology suggesting that they were the same species as shown in Table (3).

Bacillus was the common genus with six species (B. subtilis, B. atrophaeus, $B$. hemicentroti, $B$. velezensis, B. nakamurai and $B$. amyloliquefaciens). This in agree with ValleMolinares et al. (2007) and Kim et al. (2004) who reported the genus Bacillus was dominance in the earthworms gut of E. foetida and Onychochaeta boricana, respectively.

Table 3. Identification of vermicompost associated bacteria based on 16S rDNA sequence.

\begin{tabular}{ccccc}
\hline Isolates & accession No. & \% Similarity & Closest NCBI strain and accession No. & Phylum \\
\hline YFV03 & OK444809 & 100 & Bacillus atrophaeus strain NBRC 15539 & Firmicutes \\
YFV04 & OK444810 & 100 & Bacillus hemicentroti strain JSM 076093 & Firmicutes \\
YFV05 & OK444811 & 99.77 & Bacillus subtilis strain NRRL NRS-744 & Firmicutes \\
YFV06 & OK444812 & 100 & Bacillus subtilis strain NCDO 1769 & Firmicutes \\
YFV09 & OK444813 & 100 & Bacillus subtilis subsp. spizizenii strain NBRC & Firmicutes \\
YFV011 & OK444814 & 100 & 101239 & Firmicutes \\
YFV012 & OK444815 & 100 & Bacillus velezensis strain CBMB205 & Firmicutes \\
YFV013 & OK444816 & 100 & Bacillus subtilis subsp spizizenii strain NRRL B- & Firmicutes \\
YFV014 & OK444817 & 100 & 23049 & Firmicutes \\
YFV015 & OK444818 & 100 & Bacillus amyloliquefaciens strain NBRC 15535 & Firmicutes \\
\hline
\end{tabular}
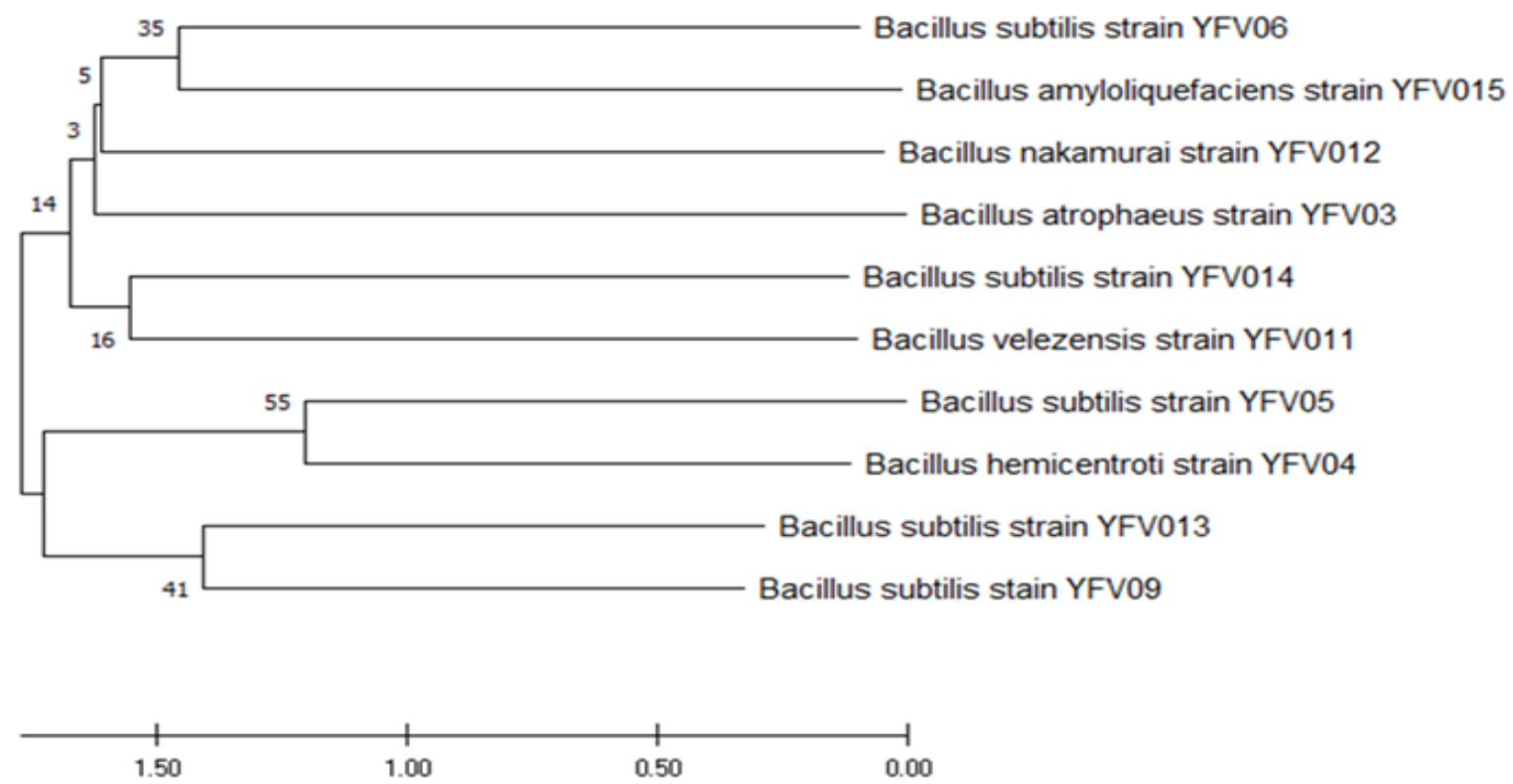

Figure 5. Phylogenetic tree of the 16S rRNA genes showing the relationships of ten vermicompost associated bacteria. The tree was constructed using neighbor-joining 
Bacillus genus is a Gram positive and spore forming bacteria that are typical live in the soil. Spore formation strategy helps the bacteria to survive and spread not only in the soil but also in the gut of the earthworms (Kim et al., 2004; Valle-Molinares et al., 2007). Similar bacterial communities are reported in vermicompost of different organic residues (Fernández-Gómez et al., 2012). Phylogenetic tree based on 16S rRNA sequences from ten vermicompost associated bacteria was based using the neighbor joining (NJ) method as shown in Figure (5). Generally, the phylogenetic tree showed that some species of the Bacillus genus are found in the same clade e.g., $(B$. subtilis and B. hemicentroti) and (B. subtilis and $B$. velezensis). However, different species of the same genus, such as Bacillus subtilis, Bacillus amyloliquefaciens and Bacillus nakamurai, shared the Bacillus atrophaeus as a common ancestor. These results demonstrate the conservative gene of these three Bacillus species was derived from Bacillus atrophaeus.

\subsection{In vitro antagonistic activity of vermicompost associated bacteria isolates}

The in vitro antagonistic effect of the ten vermicompost bacterial isolates against four phytopathogenic fungi (Fusarium solani,
Fusarium spp, Macrophomina phasolenia, and Rhizoctonia solani) on PDA media are presented in Table 4 and Figure 6. The obtained results revealed that all of the ten bacterial isolates exhibited antagonistic effects against mycelium growth of all tested phytopathogens by forming an inhibition zone. All bacterial isolates strongly inhibited the growth of $M$. phaseolina by forming inhibition zone ranged from $62.22 \%$ (YFV014) to $77.78 \%$ (YFV015) which belonged to growth inhibition categories (GIC) of 3 and 4, respectively. However, all bacterial isolates inhibited the mycelium growth of $\mathrm{R}$. solani particularly the two isolates YFV012 and YFV013 which gave the same value of inhibition (64.44\%) with GIC 3 except the isolate (YFV03) which exhibited poor antagonistic activity (48.89\%) against this fungus.

Generally, all bacterial isolates inhibited the mycelium growth of the two fungi Fusarium solani and Fusarium spp. The highest inhibition growth percentage of Fusarium solani were found in PDA plate treated with the two isolates (YFV04 and YFV011) which gave 65.74 and $62.96 \%$, respectively with GIC 3. On the other hand, the bacterial isolate YFV011 was the best against Fusarium spp with $(60.00 \%)$ of inhibition growth.

Table 4. Antagonistic activity of ten vermicompost associated bacterial isolates against phytopathogenic fungi.

\begin{tabular}{ccccc}
\hline \multirow{2}{*}{ Isolates } & \multicolumn{3}{c}{ Phytopathogens } \\
\cline { 2 - 5 } M. phasolenia & R. solani & F. solani & F. spp. \\
YFV04 & 67.41 & 48.89 & 59.26 & 54.07 \\
YFV05 & 67.41 & 53.33 & 65.74 & 54.81 \\
YFV06 & 63.70 & 60.00 & 54.63 & 51.11 \\
YFV09 & 64.44 & 55.56 & 61.40 & 50.37 \\
YFV011 & 69.63 & 60.00 & 58.33 & 54.81 \\
YFV012 & 63.70 & 53.33 & 62.96 & 60.00 \\
YFV013 & 67.41 & 64.44 & 53.70 & 54.81 \\
YFV014 & 68.15 & 64.44 & 51.85 & 56.30 \\
YFV015 & 62.22 & 57.78 & 57.41 & 55.56 \\
LSD0.05 & 77.78 & 57.78 & 53.70 & 54.81 \\
\hline
\end{tabular}

*Values are the mean of 3 replicates; the formula for PIRG is as follows: PIRG (\%) = [(R1 - R2)/R1] x 100. 
I

A

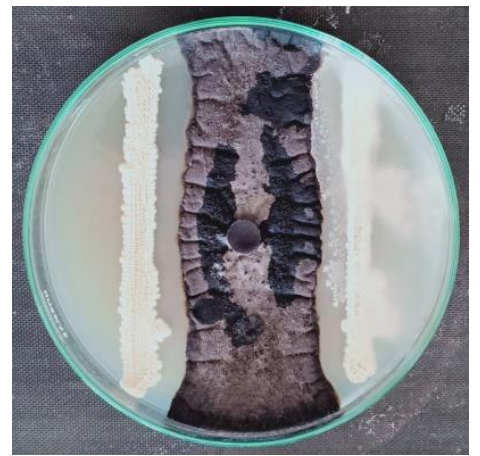

II

A

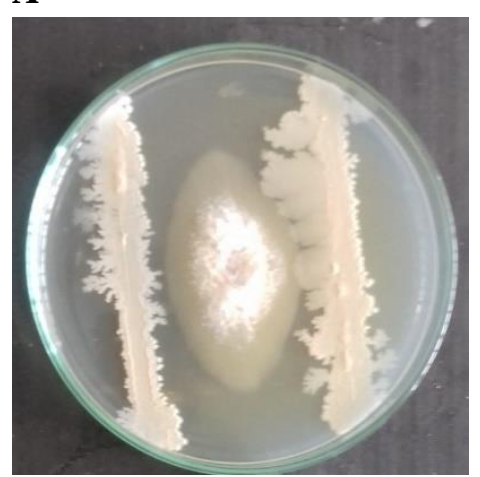

III

A

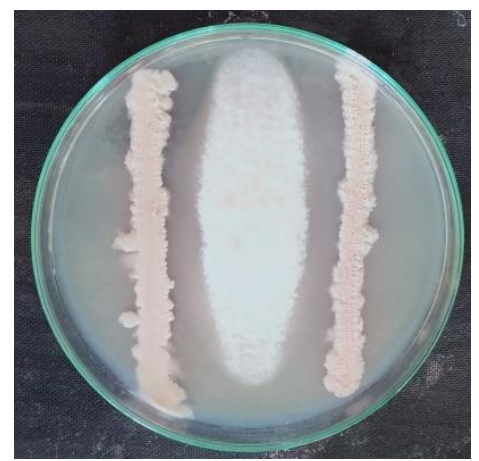

IV

A

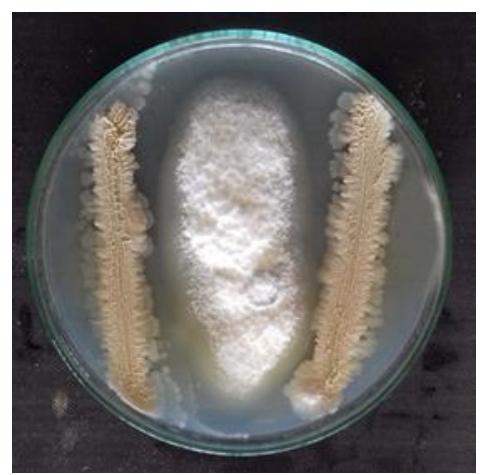

B

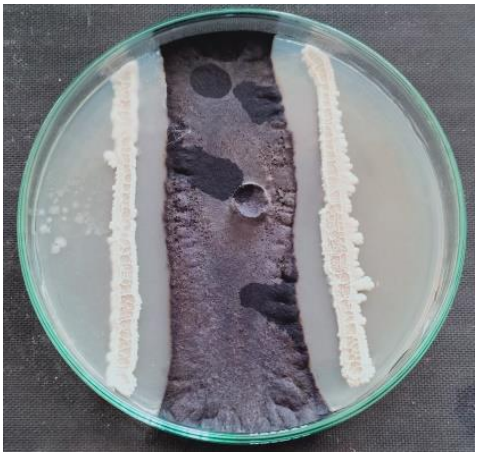

B

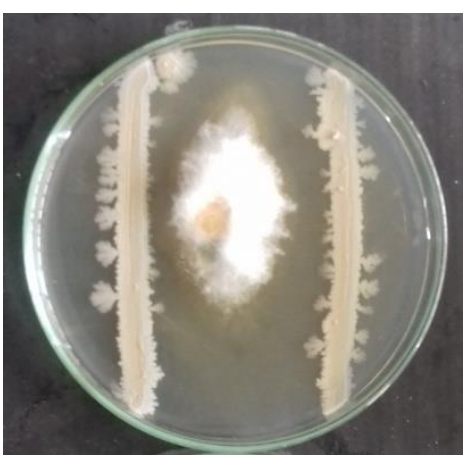

B

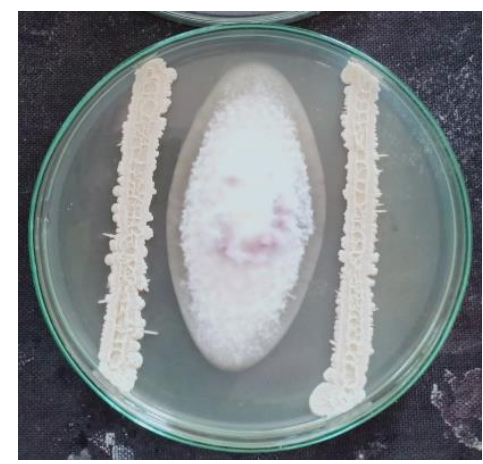

B

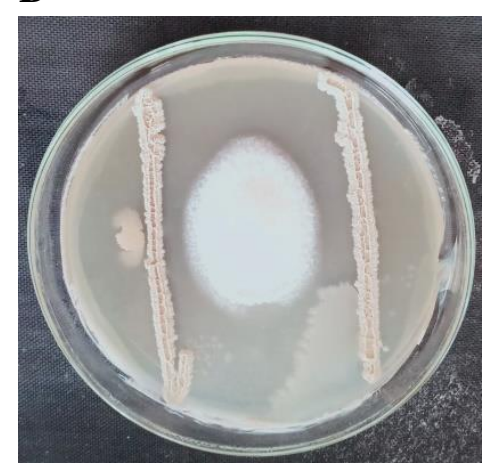

C

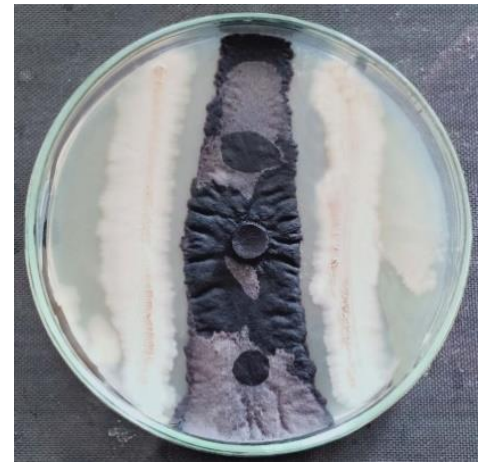

C

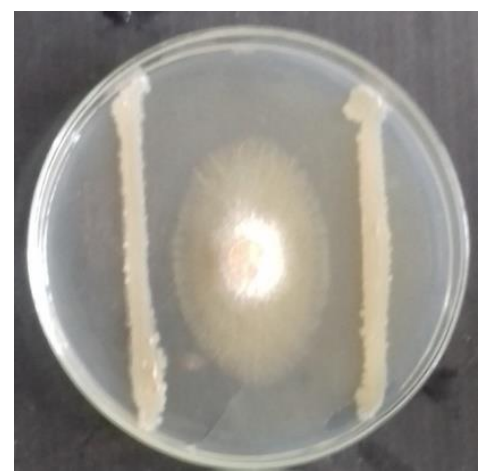

C

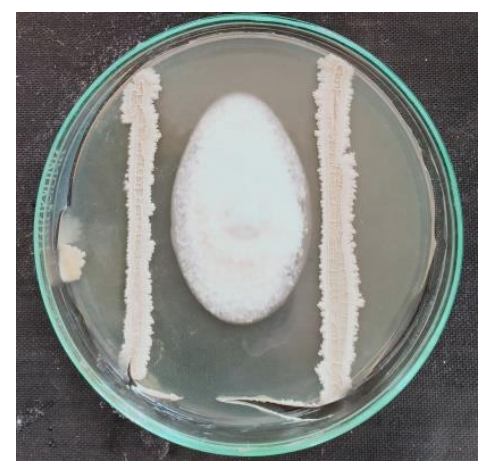

C

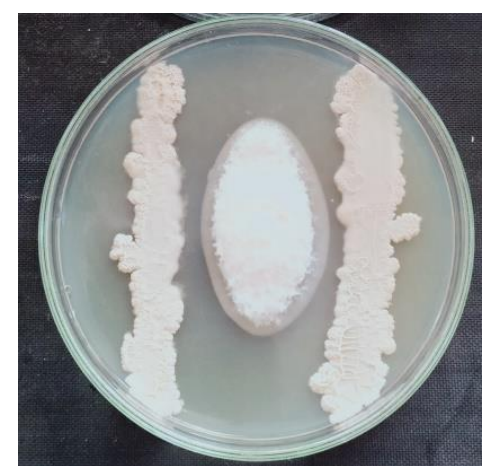

Figure 6. Inhibition effect of vermicompost bacterial isolates I: (A, YFV04; B, YFV09 and C, YFV015) against M. phaseolina, II: (A, YFV05; B, YFV012 and C, YFV013) against R. solani, III: (A, YFV04; B, YFV06 and C, YFV011) against $F$. solani, and IV: (A, YFV011; B, YFV012 and C, YFV013) against F. spp. 
Similar results were reported by Dawei et al. (2021) who found that vermicompost associated bacteria Bacillus cenocepacia had antagonistic effects against phytopathogenic fungi, including Rhizoctonia solani, $F$. oxysporum f. sp. momordicae, Phoma sorghina, and Phomopsis citri. Vermicompost is affluent with various beneficial microbes. It contains a numerous variety of antagonistic bacteria that play an important role in the bio-control of diseases caused by different soil-borne phytopathogenic fungi (Scheuerell et al., 2005; Singh et al., 2008). The in vivo and in vitro antagonistic behaviors of Bacillus species were shown by (Govindasamy et al., 2010).

\subsection{Effect of vermicompost associated bacteria on germination\% and growth indicators of cowpea seedling}

After 30 days of cultivation in the pots under greenhouse conditions, the seedling growth traits like: seedling length and vigor index in addition to germination percentage were recorded as shown in Table 5 and Figure 7. Data reveal that from the ten tested bacterial isolates only six increased the percentage of germination of cowpea seeds. Seed coated with the two isolates YFV05 and YFV014 showed the highest percentage of seed germination $(100 \%)$ followed by those treated with the four isolates YFV06, YFV09, YFV012 and YFV015 which have the same percentage of seed germination $(80 \%)$ compared to the control $(60 \%)$ while, the other bacterial isolates were equal to control (60\%).

Concerning the seedling length, seeds treated with all bacterial isolates increased significantly in length except that treated with YFV03 and YFV05 as compared with untreated control. The highest value of seedling length $(21.67 \mathrm{~cm})$ was observed when seeds treated with isolate YFV012. The vigor index increased significantly in cowpea seedling treated with all bacteria isolates except YFV03, YFV04 and YFV011. Treatment with isolate YFV014 showed the highest value of vigor index (2166.0) followed by isolate YFV05 (1775.0) and YFV012 (1733.6). The lowest vigor index (900.0) was found in untreated control seedlings as shown in (Table 5).

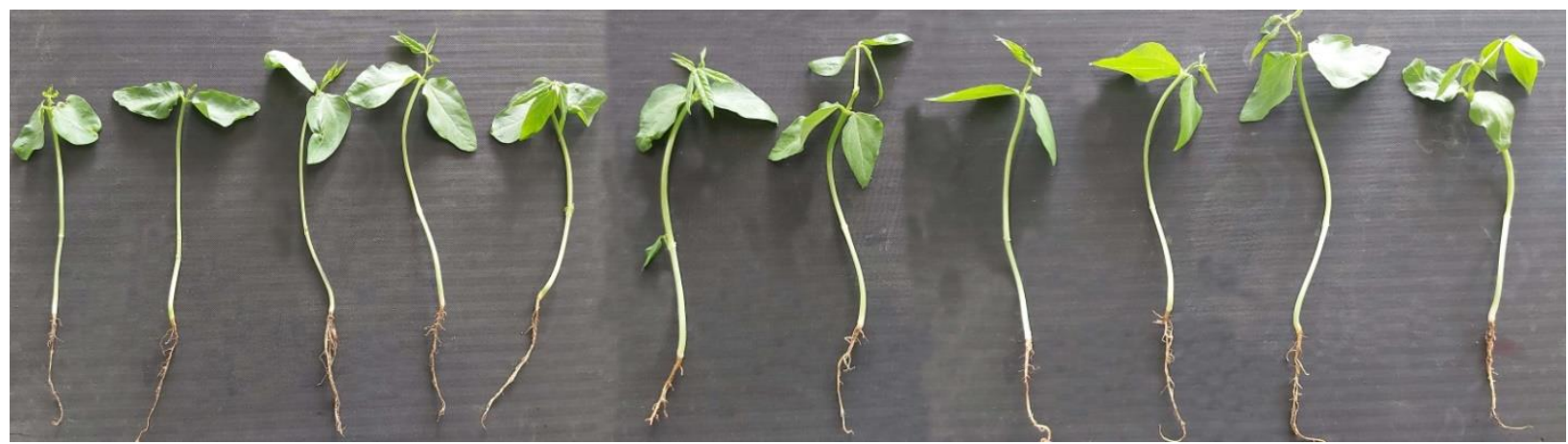

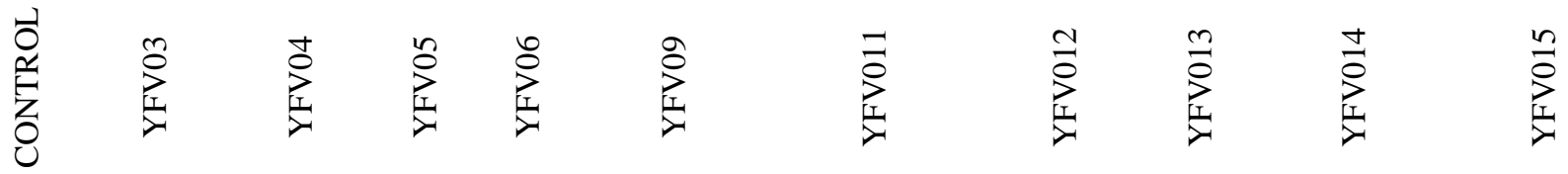

Figure 7. Effect of vermicompost associated bacterial isolates on different growth parameter of cowpea germinated seeds after 30 days of sowing.

Earthworms absorb plant growth promoting rhizo-bacteria (PGPR) such as Bacillus, Pseudomonas, Rhizobium, Azosprillium, Azotobacter, etc. from rhizospheric soil, and they might get activated or increased due to the typical environment in their digestive tract. Earthworm gut associated microbes enrich vermicompost with highly 
effective plant growth promoting bacteria (Pathma and Sakthivel, 2012). It was reported that many species of Bacillus had that ability to improve plant growth and development by producing important phytohormones such as (auxins, cytokinins and gibberellins), solubilization and mobilization of insoluble phosphate in the soil, producing siderophore and antibiotics, inhibiting production of plant ethylene hormone and stimulation of plant systemic resistance against several phytopathogens (Gutiérrez-Mañero et al., 2001; Idris et al., 2004; 2007; Richardson et al., 2009). The increment of the vigour of seedlings could be related to the cytokinins produced by Bacillus spp. in soils (Inbal and Feldman, 1982; Jagnow, 1987).

Table 5. Effect of vermicompost associated bacterial isoletes on the seedling growth indicators of cowpea.

\begin{tabular}{cccc}
\hline Isolates & \% Germination & Seedling length & Vigour index \\
\hline Control & 60.00 & 15.00 & 900.0 \\
YFV03 & 60.00 & 15.67 & 940.2 \\
YFV04 & 60.00 & 19.83 & 1189.8 \\
YFV05 & 100.00 & 17.75 & 1775.0 \\
YFV06 & 80.00 & 19.75 & 1580.0 \\
YFV09 & 80.00 & 18.83 & 1506.4 \\
YFV011 & 60.00 & 19.34 & 1160.4 \\
YFV012 & 80.00 & 21.67 & 1733.6 \\
YFV013 & 60.00 & 21.33 & 1279.8 \\
YFV014 & 100.00 & 21.66 & 2166.0 \\
YFV015 & 80.00 & 20.78 & 1662.4 \\
\hline LSD0.05 & 17.69 & 3.81 & 309.23 \\
\hline
\end{tabular}

\section{Conclusion}

Finally, it could be concluded that plant beneficial bacteria might be isolate from vermicompost which in turn can be can be play a significant role in plant growth promotion directly by producing plant growth regulators (hormones). enzymes and indirectly due to their antagonistic properties against different plant pathogens and other pests, thereby improving plant growth and decreasing the yield loss of various crops.

\section{References}

Abdul Baki, A.A., Anderson, J.D. (1973). 'Vigor determination in soybean seed by multiple criteria.', Crop Sci., 13, pp. 630 633.

Aneja, K.R. (2006). 'Experiments in Microbiology, Plant Pathology and Biotechnology.', $4^{\text {th }}$ Edition. New Delhi, pp. 245-275. ARAUJO,
Aritonang, S.P., Sidauruk, L. (2020). 'The Effect of Vermicompost on the Growth of Soybean (Glycine max L.).', International Journal of Ecophysiology, 2(1), pp. 18-23.

Balan, S.S., Nethaji, R., Sankar, S., Jayalakshmi, S. (2012). 'Production of gelatinase enzyme from Bacillus spp. isolated from the sediment sample of Porto Novo Coastal sites.', Asian Pacific Journal of Tropical Biomedicine. S1811-S1816

Bandounas L., Wierckx, N.J.P., Winde, J.H., Ruijssenaars, H.J. (2011). 'Isolation and characterization of novel bacterial strains exhibiting ligninolytic potential.', $B M C$ Biotechnology, 11, pp. 94.

Begum, M., Bora, P. (2018). 'Isolation and identification of bacterial strains in vermicompost and vermiwash', International Journal of Recent Research Review., 1(21), pp. 1-6. 
Bhawalkar, U. (2004). 'Vermiculture Ecotechnology', Bhawalkar Earthworm Research Institute, Pune, India.'

Cai, L., Gong, X., Sun, X., Li, S., Yu, X. (2018). 'Comparison of chemical and microbiological changes during the aerobic composting and vermicomposting of green waste.', Plos One, 13, e0207494

Cappuccino, J.G., Sherman N. (1996). 'In: Microbiology', A Laboratory Manual. The Benjamin/Cunning Publishing Company Inc. Menlopark, California.

Chaoui, H.I., Zibilske, L.M., Ohno, T. (2003). 'Effects of earthworms casts and compost on soil microbial activiity and plant nutrient availability.', Soil Biology and Bio- Chemistry, 35, pp. 295- 302.

Clarridge, J.E. (2004) 'Impact of 16S rRNA Gene Sequence Analysis for Identification of Bacteria on Clinical Microbiology and Infectious Diseases.', Clinical Microbiology Reviews, 17(4), pp. 840862.

Clower, C., Hay, K. (1968). 'Experiments in Microbial genetics.', Blackwell Scientific Publishers, UK, pp. 232-233.

Dawei, L., Dong, L., Li, L., Wang, Y., Zhang, Y. (2021). 'Screening and identification of antagonistic bacteria from vermicompost against Fusarium oxysporum f. sp. Cucumerinum. Acta Agriculturae Scandinavica, Section B', Soil and Plant Science, 71(4), pp. 266-272.

Denizci A.A., Kazan, D., Erarslan A. (2010). 'Bacillus marmarensis sp. nov., an alkaliphilic, protease-producing bacterium isolated from mushroom compost.', Int. J. Sys. Evol. Microbiol., 60(7), pp. 15901594.

Elbeltagy, A., Nishioka, K., Suzuki, H., Sato, T., Sato, Y.I., Morisaki, H., Mitsui, H., Minamisawa, K. (2000). 'Isolation and characterization of endophytic bacteria from wild and traditionally cultivated rice varieties.' Soil Sci. Plant Nutr., 46, pp. 617-629.

Fernández-Gómez, M.J., Nogales, R., Insam, H., Romero, E., Goberna, M. (2012). 'Use of DGGE and COMPOCHIP for investigating bacterial communities of various vermicomposts produced from different wastes under dissimilar conditions.' Science of the Total Environment, 414, pp. 664-671.

Fouts, D.E., Tyler, H.L., DeBoy, R.T., Daugherty, S., Ren, Q., Badger, J.H., Durkin, A.S., Huot, H., Shrivastava, S. Kothari, S. (2008). 'Complete genome sequence of the N2-fixing broad host range endophyte Klebsiella pneumoniae 342 and virulence predictions verified in mice.', PLoS Biol. 4: e1000141.

Gomez, K.A., Gomez, A.A. (1984). 'Statistical Procedures for Agricultural Research.', International Rice Research Institute, John Wiley \& Sons, New York, pp. 139-240.

Govindasamy V., Senthilkumar, M., Magheshwaran, V., Kumar, U., Bose, P., Sharma, V., Annapurna, K. (2010). 'Bacillus and Paenibacillus spp.: potential PGPR for sustainable agriculture.', In: Maheshwari DK (ed) Plant growth and health promoting bacteria. Springer, Berlin/Heidelberg, pp. 333-356

Gupta, R., Bisaria, V.S., Sharma, S. (2015). 'Effect of agricultural amendments on Cajanus cajan (Pigeon pea) and its rhizospheric microbial communities-A comparison between chemical fertilizers and bioinoculants.', PLOS ONE, 10, e0132770.

Gutierrez-Mañero, F. J., Ramos, B., Probanza, A., Mehouachi, J., Talon, M. (2001). 'The plant growth promoting rhizobacteria Bacillus pumilus and Bacillus licheniformis produce high amounts of physiologically active gibberelins.', Physiol Plant, 111, pp. 206-211. 
Hartman, K., Tringe, S.G. (2019). 'Interactions between plants and soil shaping the root microbiome under abiotic stress.', Biochemical Journal, 476, pp. 2705-2724

Hashimoto, S., Furuya, M., You, X., Wanibuchi, G., Tokumoto, H., Tojo, M., Shiragaki, K. (2021). 'Chemical and Microbiological Evaluation of Vermicompost made from School Food Waste in Japan.', JARQ., 55 (3), pp. 225-232.

Hayes, J.D., Wolf, C.R. (1990). 'Molecular mechanism of drug resistance.', Biochem. J., 272, pp. 281-295.

Hucker, G.J., Conn, H.J. (1923). 'Methods of Gram Staining.', N.Y. State Agr. Expt. Sta. Tech. Bull., 129.

Idris E.E., Bochow, H., Ross, H., Borriss, R. (2004). 'Use of Bacillus subtilis as biocontrol agent.VI. Phytohormonelike action of culture filtrates prepared from plant growth promoting Bacillus amyloliquefaciens FZB24, FZB42, FZB45 and Bacillus subtilis FZB37.', J. Plant Dis. Protect, 111(6), pp. 583-597.

Idris, E.E., Iglesias, D.J., Talon, M. (2007). 'Tryptophan dependent production of indole-3-acetic acid (IAA) affects level of plant growth promotion by Bacillus amyloliquefaciens FZB42.', Mol. PlantMicrobe Interact, 20(6), pp. 619-626.

Inbal, E., Feldman, M. (1982). 'The response of a hormonal mutant of common wheat to bacteria of the Azospirillium.', Israel J. Bot., 31, pp. 257-263

Jagnow, G. (1987). 'Inoculation of cereal crops and forage grasses with nitrogen fixing rhizosphere bacteria: a possible cause of success and failure with regard to yield response - a review.', Z. Pflanzenernaehr Dueng Bodenkde, 150, pp. 361-368

Kim, H.J., Shin, K.H., Cha, C.J., Hur, H.G. (2004). 'Analysis of aerobic and culturable bacterial community structures in earthworm (Eisenia foetida) intestine.', Agricultural Chemistry and Biotechnology, 47, pp. 137-142

Kiruthika, S., Padmanabha, B.V. (2018). 'Simple and quick method of DNA extraction from different parts of plant for PCR amplification.', Electronic Journal of Plant Breeding, 9(1), pp. 372 - 376.

Korsten, L., Jager, E.S. De. (1995). 'Mode of action of Bacillus subtilis for control of avocado postharvest pathogens.', $S$. Afr. Avocado Growers Assoc. Yearb., 18, pp. 124-130.

Kumar S., Stecher, G., Li, M., Knyaz, C., Tamura, K. (2018). 'MEGA X: Molecular Evolutionary Genetics Analysis across computing platforms.', Molecular Biology and Evolution, 35, pp. 1547-1549

Lee, J-H., Lee, J. (2010). 'Indole as an intercellular signal in microbial communities.', FEMS. Microbiol Rev., 34, pp. $426-444$.

Mbai, F.N., Magiri, E.N., Matiru, V.N., Ng'ang'a, J., Nyambati, V.C.S. (2013). 'Isolation and characterisation of bacterial root endophytes with potential to enhance plant growth from kenyan basmati rice.', American International Journal of Contemporary Research, 3(4), pp. 25-40.

Mulder C., Cohen, J.E., Seta“la“, H., Bloem, J., Breure, A.M. (2005). 'Bacterial traits, organism mass, and numerical abundance in the detrital soil food web of Dutch agricultural grasslands.', Ecol. Lett., 8, pp. 80-90.

Munoz-Ucros, J., Panke-Buisse, K., Robe, J. (2020). 'Bacterial community composition of vermicompost treated tomato rhizospheres.' PLoS ONE, 15(4), e0230577. https://doi.org/10.1371/ journal.pone.0230577.

Pace, N.R. (1997). 'A molecular view of microbial diversity and the biosphere.', Sci., 276(5313), pp. 734-740. 
Pandey, P.K., Soupir, M.L., Ikenberry, C.D., Rehmann, C.R. (2016). 'Predicting streambed sediment and water column Escherichia coli levels at watershed scale.', J. Am. Water Resour. Assoc., 52, pp. 184-197.

Patel, H.A., Patel, R.K., Khristi, S.M., Parikh, K., Rajendran, G. (2012). 'Isolation and characterization of bacterial endophytes from Lycopersicon esculentum plant and their plant growth promoting characteristics.', Nepal J. Biotech., 2, pp. 37-52.

Pathma, J., Sakthive, N. (2012). 'Microbial diversity of vermicompost bacteria that exhibit useful agricultural traits and waste management potential.', Springer Plus, 1(26), pp. 1-19

Richardson, A.E., Barea, J.M., McNeill, A. M., Prigent-Combaret, C. (2009). 'Acquisition of phosphorus and nitrogen in the rhizosphere and plant growth promotion by microorganisms.', Plant Soil, 321, pp. 305-339.

Riviere D., Desvignes, V., Pelletier, E., Chaussonnerie, S., Guermazi, S., Weissenbach, J. (2009). 'Towards the definition of a core of microorganisms involved in anaerobic digestion of sludge.', ISMEJ., 3, pp. 700-714.

Satpathy, O., Saha, M.H., Mishra, A.S., Mishra,

S.K. (2020). 'Characterization of Bacterial Isolates in Vermicompost Produced from a Mixture of Cow dung, Straw, Neem leaf and Vegetable Wastes.', doi:

https://doi.org/10.1101/2020.07.01.18346 $7 ;$

Scheuerell, S.J., Sullivan, D.M., Mahaffee, W.F. (2005). 'Suppression of seedling damping-off caused by Pythium ultimum, and Rhizoctonia solani in container media amended with a diverse range of Pacific Northwest compost sources.', Phytopathology, 95, pp. 306-315.
Seeley, H.W., Vandemark, P.J. (1981). 'Microbes in action.', A Laboratory Manual of Microbiology, Freeman and Company, San Francisco, USA., 388.

Shayne, J. J., Hugenholtz, P., Sangwan, P., Osborne, C., Jansen, H.P. (2003). 'Laboratory cultivation of widespread and previously uncultured bacteria.', Appl. Environ. Microbiol., 69, pp. 7211-7214.

Singh R., Sharma, R.R., Kumar, S., Gupta, R.K., Patil, R.T. (2008). 'Vermicompost substitution influences growth, physiological disorders, fruit yield and quality of strawberry (Fragaria $\mathrm{x}$ ananassa Duch.).', Bioresour Technol, 99, pp. 8507-8511.

Sinha R.K., Agarwal, S., Chauhan, K., Valani, D. (2010). 'The wonders of earthworms and its vermicompost in farm production: Charles Darwin's 'friends of farmers' with potential to replace destructive chemical fertilizers from agriculture.', Agricultural sciences, 1, pp. 76-94

Sivasankari, B., Anandharaj, M. (2014). 'Isolation and Molecular Characterization of Potential Plant Growth Promoting Bacillus cereus GGBSTD1 and Pseudomonas spp. GGBSTD3 from Vermisources.', Advances in Agriculture, pp. 1-13.

Valle-Molinares, R., Borges, S., RíosVelázquez, C. (2007). 'Characterization of possible symbionts in Onychochaeta borincana (Annelida: Glossoscolecidae). ', European Journal of Soil Biology, 43(Suppl. 1), pp. 14-18.

Wang, S., Hu, T., Jiao, Y., Wei, J., Cao, K. (2009). 'Isolation and characterization of Bacillus subtilis EB-28, an endophytic bacterium strain displaying biocontrol activity against Botrytis cinerea Pers.', Front. Agric. China, 3(3), pp. 247-252.

Whipps, J.M. (1987). 'Effect of media on growth and interactions between a range of soil-borne glasshouse pathogens and 
antagonistic fungi.', New Phytologist 107, pp. 127-142.

Yasir M., Aslam, Z., Kim, S.W., Lee, S.W., Jeon, C.O., Chung, Y.R. (2009a). 'Bacterial community composition and chitinase gene diversity of vermicompost with antifungal activity.', Bioresour Technol, 100, pp. 4396-4403.

You, X., Kimura, N., Okura, T., Murakami, S., Okano, R., Shimogami, Y., Matsumura, A., Tokumoto, H., Ogata, Y., Tojo, M.
(2019). 'Suppressive effects of vermicomposted bamboo powder on cucumber damping-off.', JARQ, 53, pp. 13-19.

Zhu, F., Hou, J., Xue, S., Wu, C., Wang, Q., Hartley, W. (2017). 'Vermicompost and gypsum amendments improve aggregate formation in bauxite residue.', Land Degradation and Development, 28(7), pp. 2109-2120. 